\title{
COVID-19 KNOWLEDGE, ATTITUDE, AND PRACTICES AMONG PAKISTANI MEDICAL AND NON-MEDICAL STUDENTS
}

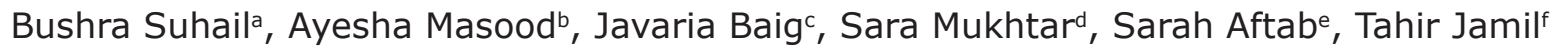 \\ ${ }^{a}$ Associate Professor, Department of Pharmacology, University College of Medicine and Dentistry \\ Lahore, Pakistan. \\ ${ }^{b}$ Assistant Professor, Department of Pathology, University College of Medicine and Dentistry Lahore, \\ Pakistan. \\ 'Liaquat College of Medicine \& Dentistry, Karachi, Pakistan. \\ ${ }^{\mathrm{d} A s s o c i a t e}$ Professor, Department of Physiology, University College of Medicine and Dentistry Lahore, \\ Pakistan. \\ eUniversity of Health Sciences Lahore, Pakistan (M.Phil Microbiology). \\ fProfessor of Internal Medicine, Faculty of Medicine, Rabigh, King Abdulaziz University, Jeddah Saudia \\ Arabia.
}

\section{ABSTRACT:}

BACKGROUND \& OBJECTIVE: This study investigated medical and non-medical students' knowledge, attitude, and preparedness regarding COVID-19 pandemic, to groom volunteers and future healthcare providers in a better way.

METHODOLOGY: This cross-sectional study was completed from April to May 2020 during the first wave of COVID-19. An online questionnaire was distributed using internet and social media (SM). The questionnaire was composed of several parts concerning to demographic data, knowledge, attitude, and practices.

RESULTS: This study included 1851 students [1041(56.54\% medical, 810(43.46\%) non-medical students)]. Medical students had significantly better knowledge about the contagious nature, spread and treatment of coronavirus. Non-medical students showed more risky behavior compared to medical students $(p=0.005)$. The use of masks and the frequency of hand washing was better among medical students as compared to non-medical students $(p<0.001 ; p<0.014$, respectively). The odds ratio indicates that students of the age group $21-25$ years (45\%) and medical students (75\%) were more likely to have a positive attitude.

CONCLUSION: This study revealed good knowledge, positive attitudes, and good practices towards COVID-19 among medical students. Still, a minority of participants from both groups revealed misconceptions and relatively poor conceptual knowledge regarding the disease.

KEYWORD: Knowledge, Attitude, Medical students, Social media.

\section{How to cite this:}

https://doi.org/10.37723/jumdc.v12i3.641

Suhail B, Masood A, Baig J, Mukhtar S, Aftab S, Jamil T.COVID-19 Knowledge, Attitude, and Practices among Pakistani medical and non-medical students. Journal of University Medical \& Dental College. 2021;12(3):169-176.https://doi.org/10.37723/jumdc.v12i3.641

This is an Open Access article distributed under the terms of the Creative Commons Attribution License (http://creativecommons.org/licenses/by/4.0), which permits unrestricted use, distribution, and reproduction in any medium provided the original work is properly cited. 


\section{INTRODUCTION:}

The present Coronavirus disease is a rapidly spreading viral pandemic. Its first case presenting as a typical pneumonia was reported in December 2019 in Wuhan city of China. The pathogen was identified after isolation and genome sequencing as a new member of the Corona family, named novel SARS-COV-2[1]. A "novel" coronavirus (nCoV) is a new strain that has not been identified previously in humans ${ }^{[2]}$. It quickly infected a large number of people in the same city, and on 30 January 2019 World Health Organization (WHO) declared it a public health emergency of international interest ${ }^{[3]}$.In December 2019, WHO declared it as pandemic and emergency protective measures like worldwide lockdown in almost all the cities, social distancing, using face masks and frequent hand washing were advised to curb the spread of disease ${ }^{[4]}$.

COVID-19 exhibits a strong person-to-person transmission. Although many vaccines are available now, but with vaccination precautionary measures observed by individuals are the best approach in avoiding the infection and reinfection. Prime preventive measures include social distancing, frequent hand washing, and observing hygienic respiratory measures like covering mouth and nose while coughing/ sneezing ${ }^{[5]}$.

Health authorities throughout the world depend on volunteers to educate the masses for observing the necessary protective measures. Medical students, especially senior classes, being in close contact with the hospitals and clinical exposure, are supposed to be well informed, motivated, and well prepared to participate in healthcare activities ${ }^{[6]}$. The KAP status of nonmedical student is not well known. Therefore, this study investigated medical and non-medical students' knowledge, attitude, and preparedness regarding COVID-19 pandemic to groom our volunteers and future healthcare providers in a better way.

\section{Corresponding Author:}

Dr. Javaria Baig

Liaquat College of Medicine \& Dentistry, Karachi, Pakistan.

Email: javaria_baig@yahoo.com

\section{METHODOLOGY:}

This cross-sectional study was completed in a private medical college after taking formal ethical permission (Reference No. DEAN/2020/ 34) from the concerned authority. The study was carried out by the snowball technique in April to May 2020; because of the lockdown, an online questionnaire was developed using a published study, 7 WHO, and CDC information. Medical students from various medical colleges and nonmedical students from other higher education institutes (HEIs) participated in this study. The questionnaire's link was circulated through emails and various social media platforms like Facebook, Twitter, WhatsApp, and Instagram. The questionnaire's front page contained information about the purpose of the study, confidentiality, and consent. This study included students of age $>18$ years and who were studying at the various medical colleges and other HEIs and were able to understand the questionnaire in English. All other students age less than 18 years were excluded from the study.

Two senior faculty members reviewed the questionnaire construct and content validity, and their suggestions were incorporated into the final version of the survey. In addition, the reliability of the questionnaire was tested by Cronbach's Alpha, which was 0.79 . The questionnaire was also validated through a pilot study involving 40 participants to verify the understanding and any ambiguity. After this pilot study, few questions were modified. The Open Epi calculator was used to calculate the sample size by taking a population of medical students about 30000 enrolled in all private and public sector medical colleges of the province. The confidence level was $95 \%$, and $5 \%$ was the margin of error, and the calculated sample size was 380. A link to the online questionnaire was disseminated via SM to all students. The questionnaire's language was English. In Pakistani medical and other HEIs, English is the medium for education, and all students expected to have good command over English. The questionnaire was composed of two parts. The first part gathered information about the participants' demographic features, including age, gender, marital status, student status, and family members. The second section of the questionnaire was composed of 14,6 , and 3 questions concerning knowledge, attitudes, 
and practices against the COVID-19 pandemic, respectively. The responses were gathered in "correct and incorrect," "five-point Likert scale," and three-point scale categories. "For calculating knowledge score, one point was awarded for the correct answer and zero for an incorrect answer and $<50 \%, 51-75 \%$, and $>75$ scores were considered poor, moderate, and good, respectively. ${ }^{\prime \prime \prime}$ For attitude, marking ranged from minus to plus (true answer +1 and false and not sure -1), and an individual's scores in plus indicated a positive attitude. In contrast, the negative attitude was indicated in minus" [8].

The Social Sciences Statistical Package 24 was used to analyze the data. Using a chi-square test, we calculated the percentages and frequencies, and determined whether the differences between the frequencies were statistically significant. Linear regression was employed to the knowledge score and logistic regression to the attitude to find out their association with gender, age groups, marital status, student groups, education, family members.

Table-I: Comparison of general demographic characteristics of all the students with COVID-19 knowledge score.

\begin{tabular}{|c|c|c|c|c|c|}
\hline \multicolumn{2}{|c|}{ Variables } & Poor N(\%) & Moderate $\mathrm{N}(\%)$ & Good N(\%) & p-value \\
\hline \multirow{2}{*}{ Gender } & Male & $105(10)$ & $96(13.1)$ & $9(13.6)$ & \multirow[t]{2}{*}{0.108} \\
\hline & Female & $946(90)$ & $638(86.9)$ & $57(86.4)$ & \\
\hline \multirow{3}{*}{ Age (years) } & $<21$ & 535(50.9) & 292(39.8) & $18(27.3)$ & \multirow[t]{3}{*}{$<0.001$} \\
\hline & $21-25$ & $507(48.2)$ & $423(57.6)$ & $44(66.7)$ & \\
\hline & $>25$ & $9(.9)$ & $19(2.6)$ & $4(6.1)$ & \\
\hline \multirow{2}{*}{ Marital status } & Married & $34(3.2)$ & $23(3.1)$ & $6(9.1)$ & \multirow[t]{2}{*}{$<0.001$} \\
\hline & Unmarried & $1017(96.8)$ & $711(96.9)$ & $60(90.9)$ & \\
\hline \multirow{2}{*}{ Students } & Medical & $574(54.6)$ & $422(57.5)$ & $45(68.2)$ & \multirow[t]{2}{*}{0.067} \\
\hline & Non-medical & $477(45.4)$ & $312(42.5)$ & $21(31.8)$ & \\
\hline \multirow{3}{*}{ Education } & Undergraduate & $830(79)$ & $577(78.6)$ & $51(77.3)$ & \multirow{3}{*}{0.827} \\
\hline & Graduate & $161(15.3)$ & $110(15)$ & $9(9.1)$ & \\
\hline & Postgraduate & $60(5.7)$ & $47(6.4)$ & $6(9.1)$ & \\
\hline \multirow[t]{3}{*}{ Family members } & $1-3$ & $50(4.8)$ & $44(6)$ & $5(7.6)$ & \multirow[t]{3}{*}{0.137} \\
\hline & $4-6$ & $672(63.9)$ & $496(67.6)$ & $39(59.1)$ & \\
\hline & $>7$ & $329(31.3)$ & $194(26.4)$ & $22(33.3)$ & \\
\hline
\end{tabular}


Table-II: Comparison of COVID-19 perception of various attitudes among medical and non-medical students.

\begin{tabular}{|c|c|c|c|c|}
\hline Variables & Response & $\begin{array}{c}\text { Med Students } \\
\text { N ( } \%)\end{array}$ & $\begin{array}{c}\text { Non-Med students } \\
\text { N(\%) }\end{array}$ & p-value \\
\hline \multirow{5}{*}{$\begin{array}{l}\text { What is your perception } \\
\text { of the dangerousness of } \\
\text { COVID-19? }\end{array}$} & Seriously dangerous & $645(62)$ & $534(65.9)$ & \multirow{5}{*}{0.141} \\
\hline & Very dangerous & $211(20.3)$ & $136(16.80$ & \\
\hline & Dangerous & $164(15.8)$ & $115(14.2)$ & \\
\hline & Like the common flu & $12(1.2)$ & $14(1.7)$ & \\
\hline & Not dangerous & $9(.9)$ & $11(1.4)$ & \\
\hline \multirow{5}{*}{$\begin{array}{l}\text { What is your perception } \\
\text { of level of risk of } \\
\text { contracting COVID-19 } \\
\text { infection? }\end{array}$} & Most risk & $369(35.4)$ & $372(45.9)$ & \multirow{5}{*}{$<0.001$} \\
\hline & High risk & $472(45.3)$ & $294(36.4)$ & \\
\hline & Moderate risk & $151(14.5)$ & $86(10.6)$ & \\
\hline & $\begin{array}{l}\text { Risk similar to that } \\
\text { of contracting the } \\
\text { common cold }\end{array}$ & $36(3.5)$ & $35(4.3)$ & \\
\hline & No risk & $13(1.2)$ & $23(2.8)$ & \\
\hline \multirow{3}{*}{$\begin{array}{l}\text { Can eating garlic prevent } \\
\text { infection with the } \\
\text { coronavirus? }\end{array}$} & Yes & $118(11.3)$ & $167(20.6)$ & \multirow[t]{3}{*}{$<0.001$} \\
\hline & No & $466(44.6)$ & $267(33)$ & \\
\hline & Not sure & $457(43.9)$ & $376(46.4)$ & \\
\hline \multirow{3}{*}{$\begin{array}{l}\text { Will warm weather } \\
\text { stop the outbreak of } \\
\text { COVID-19? }\end{array}$} & Yes & $351(33.7)$ & $371(45.8)$ & \multirow[t]{3}{*}{$<0.001$} \\
\hline & No & $380(36.5)$ & $199(24.6)$ & \\
\hline & Not sure & $310(29.8)$ & $240(29.6)$ & \\
\hline \multirow{3}{*}{$\begin{array}{l}\text { "If you knew there was a } \\
2 \% \text { chance that animals } \\
\text { e.g camels are a source } \\
\text { for the transmission of } \\
\text { Corona virus, would you } \\
\text { consume camels' milk or } \\
\text { meat?" }\end{array}$} & Yes & $51(4.9)$ & $58(7.2)$ & \multirow{3}{*}{0.005} \\
\hline & No & $831(79.8)$ & $596(73.6)$ & \\
\hline & Not sure & $159(15.3)$ & $156(19.3)$ & \\
\hline \multirow{4}{*}{$\begin{array}{l}\text { How do you normally } \\
\text { treat yourself when you } \\
\text { get a cough or fever? }\end{array}$} & $\begin{array}{l}\text { Self-medication like } \\
\text { Antibiotics }\end{array}$ & $412(39.6)$ & $305(37.7)$ & \multirow{4}{*}{0.009} \\
\hline & Consult Doctor & $468(45)$ & $331(40.9)$ & \\
\hline & $\begin{array}{l}\text { Google my } \\
\text { symptoms }\end{array}$ & $14(1.3)$ & $12(1.5)$ & \\
\hline & $\begin{array}{l}\text { Local remedies like } \\
\text { steam }\end{array}$ & $147(14.1)$ & $162(20)$ & \\
\hline
\end{tabular}

Table-III: Comparison of attitudes of medical and non-medical students about COVID-19.

\begin{tabular}{|c|c|c|c|}
\hline Attitude & Med Students n(\%) & Non-Med students n(\%) & p-value \\
\hline Negative & $345(33.1)$ & $384(47.4)$ & \multirow{2}{*}{0.001} \\
\hline Positive & $696(66.9)$ & $426(52.6)$ & \\
\hline
\end{tabular}


Table-IV: Comparison of COVID-19 practices between medical and non-medical students.

\begin{tabular}{|c|c|c|c|c|}
\hline Variables & Response & $\begin{array}{c}\text { Med Students } \\
\mathrm{n}(\%)\end{array}$ & $\begin{array}{c}\text { Non-Med students } \\
\mathrm{n}(\%)\end{array}$ & p-value \\
\hline \multirow{3}{*}{$\begin{array}{l}\text { What is your daily surgical } \\
\text { mask use? }\end{array}$} & Never & 177(17) & $196(24.2)$ & \multirow{3}{*}{$<0.001$} \\
\hline & Sometimes & $678(65.1)$ & $496(61.2)$ & \\
\hline & $\begin{array}{l}\text { Every day at all } \\
\text { times }\end{array}$ & 186(17.9) & $118(14.6)$ & \\
\hline \multirow{3}{*}{$\begin{array}{l}\text { What is your frequency of } \\
\text { washing hands per day? }\end{array}$} & $\mathrm{Nil}$ & $4(.4)$ & $9(1.1)$ & \multirow[t]{3}{*}{0.014} \\
\hline & 2-4 times & $145(13.9)$ & $143(17.7)$ & \\
\hline & $>4$ times & $892(85.7)$ & $658(81.2)$ & \\
\hline \multirow{3}{*}{$\begin{array}{l}\text { What is your frequency } \\
\text { of using soap for hand } \\
\text { washing per day? }\end{array}$} & $\mathrm{Nil}$ & $2(.20)$ & $5(.6)$ & \multirow[t]{3}{*}{0.112} \\
\hline & Sometimes & $141(13.5)$ & $129(15.9)$ & \\
\hline & Every time & $898(86.3)$ & $676(83.5)$ & \\
\hline
\end{tabular}

Linear regression analysis revealed that knowledge score was associated with the age of 21-25 years and $>25$ years, and it was also associated with the medical students. In logistic regression analysis, the odds ratio (OR) indicates that students of the age group 21-25 years were 1.45 times (or $45 \%$ ) more likely to have a positive attitude. Similarly, being medical students, 1.75 times (or $75 \%$ ) more likely to have a positive attitude Table-V).

Table-V: Linear analysis with knowledge score and logistic regression analysis of attitude with different variables.

\begin{tabular}{|c|c|c|c|c|c|c|c|c|}
\hline \multirow{3}{*}{ Variables } & \multicolumn{4}{|c|}{ Knowledge score } & \multicolumn{4}{|c|}{ Attitude } \\
\hline & \multirow{2}{*}{$\begin{array}{l}\text { Exp } \\
(B)\end{array}$} & \multirow[b]{2}{*}{ p-value } & \multicolumn{2}{|c|}{$\begin{array}{c}95.0 \% \\
\text { Confidence } \\
\text { Interval for B }\end{array}$} & \multirow[b]{2}{*}{$\operatorname{Exp}(B)$} & \multirow[b]{2}{*}{ p-value } & \multicolumn{2}{|c|}{$\begin{array}{l}95.0 \% \text { Confidence } \\
\text { Interval for B }\end{array}$} \\
\hline & & & $\begin{array}{l}\text { Lower } \\
\text { Bound }\end{array}$ & $\begin{array}{l}\text { Upper } \\
\text { Bound }\end{array}$ & & & $\begin{array}{l}\text { Lower } \\
\text { Bound }\end{array}$ & $\begin{array}{l}\text { Upper } \\
\text { Bound }\end{array}$ \\
\hline Female & -.235 & 0.081 & -.499 & 0.029 & 0.780 & 0.121 & 0.570 & 1.068 \\
\hline $21-25$ & 0.404 & 0.000 & 0.237 & 0.571 & 1.450 & 0.000 & 1.192 & 1.762 \\
\hline$>25$ & 1.029 & 0.003 & 0.354 & 1.703 & 1.058 & 0.888 & 0.485 & 2.308 \\
\hline Married & -.043 & 0.858 & -.513 & 0.428 & 0.806 & 0.436 & 0.468 & 1.387 \\
\hline $\begin{array}{l}\text { Medical } \\
\text { Students }\end{array}$ & 0.258 & 0.002 & 0.091 & 0.425 & 1.755 & 0.000 & 1.445 & 2.132 \\
\hline Graduate & 0.010 & 0.931 & -.219 & 0.239 & 0.960 & 0.762 & 0.735 & 1.253 \\
\hline Postgraduate & 0.262 & 0.134 & -.081 & 0.605 & 1.118 & 0.590 & 0.745 & 1.680 \\
\hline $\begin{array}{l}\text { Family members } \\
4-6\end{array}$ & -.133 & 0.476 & -.498 & 0.233 & 1.089 & 0.696 & 0.711 & 1.667 \\
\hline $\begin{array}{l}\text { Family members } \\
\qquad>7\end{array}$ & -.333 & 0.088 & -.714 & 0.049 & 0.987 & 0.956 & 0.633 & 1.541 \\
\hline
\end{tabular}

a. Dependent variable: knowledge score 


\section{DISCUSSION:}

The response of a society towards a pandemic is the decisive factor in controlling its spread in the masses. If the active part of society is well versed with the mode of spread of the disease and is observing the precautionary measures to combat its seriousness, then one can expect an effective combined resistance against the disease ${ }^{[9]}$. Almost one-third of study participants used SM for their knowledge related to COVID-19. Internet and SM remain at the top in educating the masses in emergencies like a present pandemic of COVID-19[10]. Multiple international studies have highlighted the role of SM in educating the masses ${ }^{[1,12]}$. Other relevant sources being the teachings by healthcare professionals and information gained by sources like television programs, newspapers, and by different NGOs. Bhagavathula et al., recommended that healthcare professionals be careful while using COVID-19 information. There is a plethora of disinformation spreading via social media and unauthentic websites ${ }^{[13]}$. Therefore, the source of information should be authentic and scientific. It is also the social duty of SM users not to disseminate unauthentic information and rumors to others and seek information from authentic sources. Interestingly, in the current study, the unmarried participants in both the medical and non-medical students were better informed as seen in other studies as well[14,15]. The unmarried group probably had more time for academic activities than married ones who have many family commitments.

The medical students were more knowledgeable,but the non-medical group showed better perception regarding the risk factors in contracting COVID-19as highlighted in another study ${ }^{[15]}$. Misconceptions regarding local remedies for prevention and management like eating garlic was equally prevalent in both the groups. The majority of medical students believed that the virus is heat-labile and would disappear during the coming warm months, such misconception has been highlighted in other studies too ${ }^{[16,17]}$.In this study, medical students were well informed regarding the disease control measures, as is also pointed out by Peng $Y$ et $\mathrm{al}^{[18]}$. Majority of our participants had positive attitudes and were of the opinion that we could control the spread of disease by observing precautionary measures. Studies carried out in Saudi Arabia\& Pakistan have pointed out similar attitudes among medical and pharmacy students $[19,20]$. Moreover, because of the fast spread and thousands of mortalities across the world, have created fear among the population. Mass media is overflowing with corona news, and SM is disseminating information swiftly. Hence, the knowledge scores were good, and attitude was more positive among our study participants, especially among medical students. The SM could be one of the important factors in better knowledge and positive attitudes among the study participants.

Our participants showed positive practices and preparedness for this crisis. Provision of proper knowledge and perceptions are the essential requirements for the proper preparedness of society. Gasch et al., revealed multidirectional efforts to prepare the masses for controlling the epidemic/pandemic situations ${ }^{[21]}$. Galvin J pointed out the results of ineffective preparedness in nursing students resulting in increased morbidity and mortality in nursing students in Wales, UK ${ }^{[22] .}$ The present study participants agreed to the point of maintaining social distance practice while meeting with friends and relatives. Females showed positive practices of COVID-19. Few other studies have pointed out similar trends in their studies ${ }^{[18,23]}$.In contrast to other studies, unmarried students showed much seriousness and a positive attitude compared to the married group $^{[14,24]}$. The negative effects of this pandemic on the country's economic conditions and mental and social wellbeing are enormous ${ }^{[25]}$. Still, it is not clear that it will vanish forever or will remain on this planet like Flu, MERS, SARS, HIV, etc. Therefore, public health educators, $\mathrm{MOH}$, and broadcasting media should educate the people on how to live with this virus wisely and safely. The public needs to be educated about COVID-19's preventive measures in order to develop costeffective strategies for the long-term fight against it ${ }^{[26]}$. People will have to follow the government's issued Standard Operating Procedures (SOPs) to carry out day-to-day work. We have to move on to the workplace by observing WHO and our Ministry of Health instructions, to observe strict precautionary measures to protect ourselves and other society members. 
LIMITATIONS: The sample collection technique was one of the limitations of our study, and in such type of studies reporting bias also found.

CONCLUSION: Our study revealed good knowledge, a positive attitude, and good practices towards COVID-19 in young students of Punjab. Still, a minority of participants revealed misconceptions and relatively poor conceptual knowledge regarding the disease. The present study findings may prove as baseline guidance regarding the provision of correct information \& awareness to the younger generation.

\section{ACKNOWLEDGEMENTS: None GRANT SUPPORT AND FINANCIAL DISCLOSURE: None CONFLICT OF INTEREST: None}

\section{REFERENCES:}

1. Ruan Q, Yang K, Wang W, Jiang L, Song J. Clinical predictors of mortality due to COVID-19 based on an analysis of data of 150 patients from Wuhan, China. Journal of Intensive Care Medicine. 2020;3: 1-3. Doi: 10.1007/s00134-020-05991-x.

2. Epidemiology Working Group for NCIP Epidemic Response, ChineseCenterforDisease Control and Prevention. The epidemiological characteristics of an outbreak of 2019 novel coronavirus diseases (COVID-19) in China. Zhonghua Liu Xing Bing Xue Za Zhi. 2020;41(2):145-151. Doi: $10.3760 / \mathrm{cma}$.j.is sn.0254-6450.2020.02.003.

3. Sohrabi C, Alsafi Z, O'Neill N, Khan M, Kerwan A, Al-Jabir A, et al. World Health Organization declares global emergency: A review of the 2019 novel coronavirus (COVID-19). International Journal of Surgery. $2020 ; 76: 71$ 76. Doi: $10.1016 / j$.ijsu.2020.02.034.

4. Cucinotta D, Vanelli M. WHO declares COVID-19 a pandemic. Acta Bio Medica: AteneiParmensis. 2020;91(1):157-160.Doi: 10.23750/abm.v91i1.9397

5. World Health Organization. Modes of transmission of virus causing COVID-19: implications for IPC precaution recommendations: scientific brief, 2020 [cited 27 March 2020]. In: World Health Organization. [Internet]. Available from: https://www. who.int/news-room/commentaries/detail/ modes-of-transmission-of-virus-causing- covid-19-implications-for-ipc-precautionrecommendations.

6. Harvey A. Covid-19: Medical schools given powers to graduate final year students early to help NHS. British Medical Journal. 2020;368:m1227. Doi: 10.1136/bmj.m1227.

7. Srichan $\mathrm{P}$, Apidechkul $T$, Tamornpark R, Yeemard F, Khunthason S, Kitchanapaiboon S, et al. Knowledge, attitude and preparedness to respond to the 2019 novel coronavirus (COVID-19) among the bordered population of northern Thailand in the early period of the outbreak: a cross-sectional study. Available at SSRN 3546046. 2020.

8. Baig M, Jameel T, Alzahrani SH, Mirza AA, Gazzaz ZJ, Ahmad T, et al. Predictors of misconceptions, knowledge, attitudes, and practices of COVID-19 pandemic among a sample of Saudi population. PLoS ONE. 2020; 15: e0243526. Doi:10.1371/journal. pone. 0243526 .

9. Tian H, Liu Y, Li Y, Wu CH, Chen B, Kraemer $M U$, et al. An investigation of transmission control measures during the first 50 days of the COVID-19 epidemic in China. Science. 2020;368(6491):638-642.Doi: 10.1126/ science.abb6105.

10. Ali MY, Bhatti R. COVID-19 (Coronavirus) Pandemic: Information Sources Channels for the Public Health Awareness. Asia Pacific Journal of Public Health. 2020; 32(4): 168-169. Available from: Doi: $10.1177 / 1010539520927261$

11. Naser AY, Dahmash EZ, Alwafi H, Alsairafi ZK, Al Rajeh AM, Alhartani YJ, et al. Knowledge and practices towards COVID-19 during its outbreak: a multinational cross-sectional study. MedRxiv. 2020.

12. Geldsetzer P. Knowledge and perceptions of COVID-19 among the general public in the United States and the United Kingdom: a cross-sectional online survey. Annals of Internal Medicine. 2020;173(2):157-160.

13. Bhagavathula AS, Aldhaleei WA, Rahmani J, Mahabadi MA, Bandari DK. Novel coronavirus (COVID-19) knowledge and perceptions: a survey on healthcare workers. MedRxiv. 2020.

14. Saqlain M, Ahmed A, Gulzar A, Naz S, Munir MM, Ahmed $Z$, et al. Public Knowledge and Practices regarding COVID-19: A crosssectional survey from Pakistan. MedRxiv. 2020:1-24. 
15. Zhong BL, Luo W, Li HM, Zhang QQ, Liu XG, Li WT, et al. Knowledge, attitudes, and practices towards COVID-19 among Chinese residents during the rapid rise period of the COVID-19 outbreak: a quick online crosssectional survey. International Journal of Biological Science. 2020;16(10):1745-1752. Doi: $10.7150 /$ ijbs.45221

16. Wadood MA, Mamun AS, Rafi MA, kamrul Islam M, Mohd S, Lee LL, et al. Knowledge, attitude, practice and perception regarding COVID-19 among students in Bangladesh: Survey in Rajshahi University. medRxiv. 2020. [Preprint]. 2020 [cited 2020 June 16]. Available from: https://www.medrxiv.org/ content/10.1101/2020.04.21.20074757v1

17. Puvvada RK, Undela K, Palaksha MS, Gupta MB. Knowledge and Beliefs of General Public of India on COVID-19: A Cross-sectional Survey. EAS Journal of Pharmacy and Pharmacology.2020;2(5): 186-192. Doi: 10.36349/easjpp.2020.v02i05.004

18. Peng Y, Pei C, Zheng Y, Wang J, Zhang K, Zheng $Z$, et al. Knowledge, attitude and practice associated with COVID-19 among university students: A cross-sectional survey in China.2020. Doi: 10.21203/rs.3.rs-21185/ v3

19. Noreen K, Rubab Z, Umar M, Rehman R, Baig $M$, Baig F. Knowledge, attitudes, and practices against the growing threat of COVID-19 among medical students of Pakistan. PLoS ONE. 2020;15: e0243696. Doi:10.1371/ journal. pone.0243696.

20. Tariq S, Tariq S, Baig M, Alam SS. Adequacy of preventive measures, awareness, and attitude regarding the COVID-19 pandemic among university pharmacy students. Pharmacy Education. 2020; 20:283-289. Doi: 10.46542/pe.2020.202.283289

21. Cervera-Gasch Á, González-Chordá VM, Mena-Tudela D. COVID-19: Are Spanish medicine and nursing students prepared?. Nurse Education Today. 2020;92:104473.

22. Galvin J, Richards G, Smith AP. A longitudinal cohort study investigating inadequate preparation and death and dying in nursing students: IMPLICATIONS for the aftermath of the COVID-19 pandemic. Frontiers in Psychology. 2020; 11:2206.
23. De La Vega $R$, Ruíz-Barquín $R$, Boros $S$, Szabo A. Could attitudes toward COVID-19 in Spain render men more vulnerable than women?. Global Public Health. 2020;15(9):1278-1291.

24. Tomar BS, Singh $P$, Nathiya D, Suman S, Raj $P$, Tripathi $S$, et al. Indian communitys Knowledge, Attitude \& Practice towards COVID-19. 2021;37(1):48-56. Doi: 10.4103/ ijsp.ijsp_133_20

25. Ahmad T, Haroon, Baig M, Hui J. Coronavirus Disease 2019 (COVID-19) Pandemic and economic impact. Pakistan Journal of Medical Sciences. 2020;36(COVID19-S4): S73-S78.

26. Tariq S, Tariq S, Baig M, Saeed M. Knowledge, awareness, and practices regarding the novel coronavirus among a sample of a Pakistani population: a cross-sectional study. Disaster Medicine and Public Health Preparedness.2020;1-6.Doi: 10.1017/ dmp.2020.408.

\section{Author's Contribution:}

Bushra Suhail: Designed and conducted the research, analyzed the data and prepared the manuscript.

Ayesha Masood: Collected the data, carried out the literature search, helped in analyzing the data and prepared the manuscript.

Javaria Baig: Carried out the literature search, prepared and revised the manuscript.

Sara Mukhtar: Carried out the literature search, helped in analyzing the data and revised the manuscript.

Sarah Aftab: Final approval of the version to be published.

Tahir Jamil: Helped in analyzing the data and revised the manuscript.

Submitted for Publication: 12-07-2021

Accepted After revision: 16-08-2021 